UCRL--15507

DE83 002278

\author{
BECHTEL JOB 15340 FOR \\ LAWRESCE LIVERYORE HAT IONAL LABORATORY \\ COHCEPTUAT CAPITAL COST ESTDATE AND FACILITY DESIGN \\ OF THE MIRROR FUSION \\ TECHNOLOGY DEYONSTRATION FACILITY
}

Prepared by

Bechtel Group, Inc.

PO Box 3965

San Francisco, CA 94119

September 1982

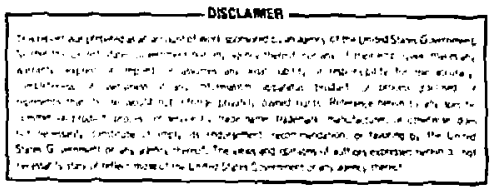

MOTICE

PORTIONS OF THIS REPORT PRE ILLEEIBI.E. It has been reproduced from the test availablo" copy to permit the bragdest possibte avilability. 
This report contains contributions by Bechtel Group, Inc. to Lawrence Livermore National Labotatory (LLNL) for the final report on the conceptual design of the Mirzor Fusion Technology Demonstration Facility (IDF). Included in this report are the following contributions:

- Conceptual Capital Cost Estimate

- Structural Design

- Plot Plan and Plant Arrangement Drawings

The conceptual capital cost estimate is prepared in a format suitable for inclusion as a section in the TDF final report. The structural design and drawings are prepared as partial inputs to the TDF final report section on facilities design, which is being prepared by the FEDC. 
CONTENTS

Page

Conceptual Capital Cost Estimate

Appendix A: Structural Derign

$A-1$

Appendix B: TDF Plot Plan and Plant Arrangement Drawings

B-1 
TOTAL CAPITAL COSTS

The toial capital costs eatimated for the Technology Demonatration Facility (TDF) are shom in Table 1 . This estimate is in millions of mid-2982 dollars and has the following qualifications:

- The extimate uas prepared assuning that the acope of services will be that of a prime contractor responsible to the ouner for engineering, procurement, and construction.

- Equipwent and materialo will be procured from U.S. sources, and lead tiaes will be able to support the project schedule vithout cost penalties.

- Sufficient anual and nonmanual personnel to complete the project within the construction schedule is assumed to be available in the project vicinity.

- Existing water sources and power vill be adequate for the requirements of this project.

\section{Direct Costs}

The direct costs shown in Table 2 include the plant equipment, materials and subcontracts, and installation labor associated with the permanent facilities, systems, and equipment.

The costs of the TDF equipment vere estimated by the engineers and organizations responsible for the derign and specification of that equipment (Table 3). A cost deta collection methodology was developed to ensure that all components and systems were included in the cost estimate, and to ensure that all cost deta are on a common basis.

The IDF work breakdown atructure was first arranged to correspond to the standard accounts for fusion cost estimates developed by Battelle (Ref. 1). The engineer responsible for the account developed the work breakdown below the level shown on Table 2. By reviewing the detailed 
Table I

TDP CAPITAL COST SLMAARY

(Mid-1982\$ $\$ 10^{6}$ )

\begin{tabular}{lr} 
Description & Cost \\
\hline Direct cost & 653 \\
Indirect cost & $\underline{110}$ \\
Total field cost & 763 \\
Home office cost & 191 \\
Owner's cost (operating entity) & 38 \\
Contingency & 298 \\
\hline Total capital cost & $\underline{1290}$
\end{tabular}


Table 2

TDF DIRECT COST SUMMARY

(Mid-1982\$1000)

Account
21
22.01 .01
22.01 .02
22.01 .03
22.01 .04
22.01 .05
22.01 .06
22.01 .07
22.02
22.03
22.04
22.05
22.06
22.07
24
25

Description

Structures and site facilities vacuum vessel and beam dumpo

$$
\text { Shield }
$$

Magnets

Heating and fueling

Primary structure

Reactor vacuum systems

Power aupply switching and energy scorage

Heat transport system

Cryogenic system

Radioactive waste treatment and disposal

Fuel handling and storage

other rector plant equipment

Instrumentation and controls

Electric plant equipment

Miscellaneous plant equipment

\section{BOP Equipment}

BOP Piping

BOP Instrumentation

Electrical

Total direct cost

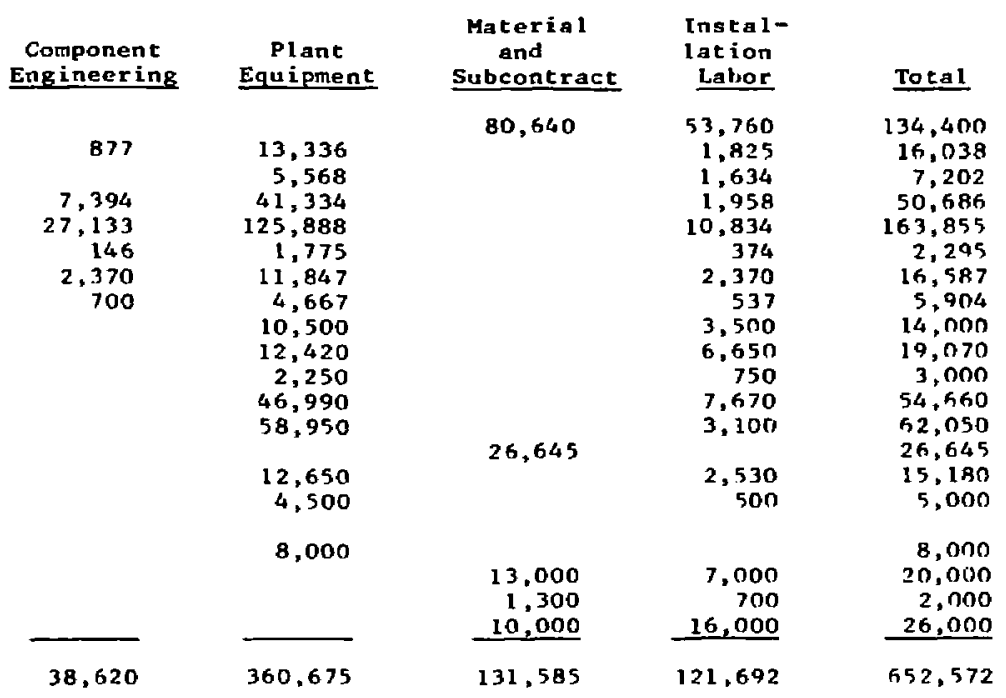


Table 3

IDF CAPITAL COST ACCOUNTS

\begin{tabular}{|c|c|c|}
\hline Account & Description & Responsible Organization \\
\hline 21 & Structures and site facilities & $\begin{array}{l}\text { Fusion Engineering } \\
\text { Design Center (FEDC) }\end{array}$ \\
\hline 22 & Reactor plant equipment & \\
\hline 22.01 .01 & Vacuum vessel & General Dynami ¿s (GD), LLNL \\
\hline 22.01 .02 & Shield & TRW \\
\hline 22.01 .03 & Magnets & GD, FEDC \\
\hline 22.01 .04 .01 & Beam heating & TRW, FEDC \\
\hline 22.01 .04 .02 & $R F$ heating & FEDC \\
\hline 22.01 .04 .03 & Fuel ing & FEDC \\
\hline 22.01 .05 & Primary structure and support & (D) \\
\hline 22.01 .06 & Reactor vacuum system & LLNL \\
\hline 22.01 .07 & $\begin{array}{l}\text { Power supply switching and } \\
\text { energy storage }\end{array}$ & FEDC \\
\hline 22.02 & Heat transport system & FEDC \\
\hline 22.03 & Cryogenic system & GD \\
\hline 22.04 & $\begin{array}{l}\text { Radioactive waste treatment } \\
\text { and disposal }\end{array}$ & FEDC \\
\hline 22.05 & $\begin{array}{l}\text { Fuel handling and storage } \\
\text { Systems }\end{array}$ & $\begin{array}{l}\text { Science Applications, Inc. } \\
\text { (SAI) }\end{array}$ \\
\hline 22.06 & Other reactor plant equipment & FEDC \\
\hline 22.07 & Instrumentation and control & TRH \\
\hline 24 & Electric plant equipment & FEDC \\
\hline 25 & Miscellaneous plant equipment & FEDC \\
\hline
\end{tabular}


account breakdown before actual cost estimating began, the cost estimating group was able to resolve omissions and redundancies early in the project.

The responsible engineers were then provided with equipment cost forms, which were used to transmit cost data on equipment, component engineering and installation. The equipment cost was defined to include the base mechanical equipment plus all required drives, piping, instrumentation, anc electrical materials that are furnished with the equipment before delivery to the jobsite. It excludes installation, freight, vendor representatives, contingency, and component engineering. The component engineering cost, which was included as a separate item, is the cost associated with the design of a first-of-a-kind component. Installation costs were reported as direct installation hours excluding nonmanual supervision. Allowances for vendor representatives, freight, and installation materials were developed by the cost estimating group.

Materials include all permanent plant materials usually purchased in bulk quantities, such as the following items:

- Earthwork

o Formwork

- Rebar and embedded metal

- Concrete

- Steel

- Pipe

- Valves and connectors

- Electrical equipment

- Wire and cable

- Conduit and cable tray

- Computers and control modules

o Field instruments and bulks 
To simplify preparation of the estimate and accurately account for all field labor, subcontracts are generally not included as such in the estimate. This method in eff $\epsilon^{-t}$ assumes that all field labor is performed by the prime contractor's wirk forces and results in essentially the same total estimated construction cost as that based on some subcontractor work. The instrumentation and control (IGC) system is the only exception to this approach. The I\&C package was estimated by TRh on a subcontract basis; this convention made it easier to integrate the $\triangle \& C$ estimate into the total plant estimate.

The materials estimate was prepared by Bechtel personnel based on scope definition developed at the FEDC.

Installation labor includes all manual labor involved directly in the erection of the permanent plant facilities, systems, and equiptrent. Typically, installation manhours were provided by the study participants and reviewed by Bechtel. Where the manhour estimates were omitted or appeared to be inconsistent with general construction experience, appropriate allowances were developed by Bechtel. An average U.S. labor rate of $\$ 22.00$ per hour including all applicable premiuns, fringes, taxes, and insurance additives was assumed for this study, based on a review of current U.S. craft labor agreements.

\section{Indirect Costs}

Indirect costs are those costs that cannot be directly identified with specific permanent plant facilities, systems, and equipment; this includes the following:

- Temporary construction facilities: temporary buildings, working areas, roads, parking areas, utizity system, and general purpose scaffolding

- Miscellaneous construction services: general job cleanup, maintenance of construction equiprent and tools, material handling, surveying, and watchmen and guards 
- Construction equipment and supplies: construction equipment, small tools, consumable supplies, and purchased utilities

- Field office: craft supervision, engineering, procurement, scheduling, personnel administration, warehousing, first aid, ard the costs of operating the field of fice

- Preliminary checkout and acceptance testing: testing of materials and equipment to ensure that components and systems are operable

- Project insurance: public liability, propercy damage, and builder's risk insurances

The costs of the facilities, supplies, and services were estimated as a percent of direct labor costs based on an evaluation of Bechtel experience on nuclear facilities and other projects of a similar magnitude and nature. This analysis resultet in an allowance for indirect costs equal to 90 percent of direct labor.

\section{Home Office Costs}

Home office costs include prelininary, definitive, and detail design engineering, cost engineering, scheduling, procurement, and project and construction management services.

The estinate of home office costs was developed based on an analysis of experience on nuclear facilities and other projects of a similar nature. This resulted in an allowance for home office costs equal to 25 percent of total field cost.

\section{Owner's Costs}

Owner's costs are those incurred by the project during engineering and construction that are not directly attributable to the prime contractor. They inclide such items as:

- Program administration and management

- Preliminary engineering

- Site investigation 
- Research and development

- Initial charges, inventory, and spares

- Startup and training

Because TDF would be a government-owned and -operated facility, a relatively small allowance of 4 percent of the total field and home office cost has been included.

\section{Contingency}

Contingency is an allowance for the ticertainty that exists within the conceptual design in quantity, pricing, or productivity and that is under the control of the engineer/constructor and within the defined scope of the project. Implicitly, the allowance will be expended during design and construction of the project and it cannot be considered as a source of funds for overruns or additions to the project scope.

Contingency excludes factors outside the control of the engineer/ constructor, such as scope changes; force majeure; regulatory, operating, safety, and environmental standards; site selection; and political and financial market conditions. Contingency has been included in the estimate at 30 percent of the total cf field, home office, and owner's costs.

DISCUSS ION OF DOST EST DMATE

\section{Cost Comparisons}

The total capital cost summary developed in Table 1 assumes that the IDF will be constructed at an undeveloped site with engineer/constructor as the prime contractor. It is also possible that the TDF will be constructed at an existing national laboratory, with the laboratory as prime contractor, and that existing facilities may be used during the construction. To estimate the indirect ccats asseciated with this type of projecr, the factors developed at the Fusion Engineering Design Center (FEDC) are employed (Ref. 2). 
The total direct cost as defined by the FEDC excludes component engineering and installation labor for the reactor plant equipment.

However, labor costs for facilities that would normally be subcontracted to industry are included as direct costs in the FEDC cost algorithms. These include:

$\begin{array}{ll}\text { Account } & \text { Description } \\ 21 & \text { Structures and site facilties } \\ 22.02 & \text { Heat transport system } \\ 22.04 & \text { Radioactive waste treatment and disposal } \\ (22.06) & \text { Other reactor plant equipment except remote } \\ 25 & \text { maintenance equipment } \\ & \text { Miscellaneous plant equipment }\end{array}$

The total direct cost of the TDF defined to be compatible with FEDC is then:

Cost Item

Equipment cost Material and subcontract Subcontract labor

Total direct cost

\section{Cost, $\$ \times 10^{6}$}

360.7

131.6

58.8

551.1

This is the cost that should be used in comparing IDF to the FED designs developed by the FEDC.

The total cost is then developed by the FEDC method as:

\section{Cost Item}

Total direct cost

Engineering and management (45\%) Installation (15\% of TDC)

Subtotal

Contingency (30\%)

Total cost
Cost, $\$ \times 10^{6}$ 
The factors are comparable to the costs developed in Tables 1 and 2 if engineering and management is identified as the component engineering, home office and owner's cost, and if installation is defined as the labor not included in the FEDC direct cost. The difference between the two total cost estimates is the indirect (field) cost. The indirect field costs will vary depending on the applicability and availability of existing facilities to support the TDF construction.

The capital cost of TDF was also estimated by LLNL, based on corstruction at LLNL and using existing facilities and services. Using the direct cost developed in Table 2, LLN experience would apply the following factors:

- Construction equipment and services $10 \%$

- LLWL project engineering $5 \%$

- Systems checkout and acceptance $5 \%$

- Project management

$2.5 \%$

At this stage in the TDF study, an uncertainty in direct cost of $\dot{\square} 20$ percent is applied to account for design and scope changes before a commitment to construct. The contingency is estimated to be 20 percent, based on LLWL project experience.

The capital cost is then estimated as:

\section{Cost Irem}

Direct cost

Indirect cost (22.5\%) Total field cost

Contingency (20\%)

Total capital cost
6

Cost, $\$ \times 10$ $\pm 131$

147

$\overline{800}$

$$
+29
$$$$
\pm 160
$$

160

$+32$

960 


\section{Direct Cost Elements}

To display the major cost elements, and to provide a basis for scaling the TDF component costs, a further breakdown of the cost accounts is shown in Table 4. The direct costs developed in Table 2 were used for this breakdown, and they include equipment, material, component engineering, and labor. 
Table 4

\section{DIRECT COST ELEMENTS}

(Mid-1982\$ x 1000)

Cost Item

1. Reactor vessel

Central cell veasel

Anchor/end cell vessel

Central cell shield

Anchor/end shield

Support structure

2. Magnets

Central celi coils

Anchor/transition coils

Choke coils

Anchor vacuun vessel

Central intercoil support
Cost

23,417

210

13,944

6,202

1,000

2,061

32,995

8,001

2,265

7,425

234

50,920

121,758

24,980

13,750

1,884

Beam dumps

4. Fuel system

Fuel injection

Purification and preparation

Water cleanup systems

Air cleanup systems

Other tritium processing

5. Maintenance equipwent

Reactor cell

Hot cell

Special purpose

22,637

24,551

11,857

3,367

14,153

19,868

11,978

8,661

162,372

58,027

59,045

16,587

11,470

7,600

6,200

1,300

6,500 
Table 4 ( cont $\left.^{1} d\right)$

Cost Iten

Cost

7. Electrical systems

Magnet power supplies

Magnet control systems

Pulsed power substation

Facility power substation

Emergency power

\begin{tabular}{rr}
\multicolumn{2}{c}{ Cost } \\
& 21,089 \\
4,391 & \\
1,518 & \\
11,508 & \\
2,040 & \\
1,632 &
\end{tabular}

8. Instrumentation and control

Supervisory control/data sygtem

13,055

26,645

Local control instrumentation

10,601

Personnel safety/interlocks

2,989

9. Facilities

Reactor building

40,000

Hot cell

24,200

Rector auxiliary bulding

17,200

Power supply building

6,000

Other buildings

30,000

Site improvements

14,400

2,600

3,000

8,000

56,000

201,400

Cooling system structures

Miscellaneous plant equipment

Bulk materials

652,572

Total direct cost 


\section{REFERENCES}

1. S.C. Schulte, T.L. Willke, and S.R. Young, Fusion Reactor Design Studies - Standard Accounts for Cost Estimates, Battelle-Pacific Northwest Laboratory, PNL-2648, May 1978.

2. Fusion Engineering Design Center, Fusion Engineering Device Design Description, ORNL/TM-7948, Decerber 1981. 
Appendix A

STRUCTURAL DESIGN

\section{SIRUCTURAL DESIGN CRITERIA}

These criteria govern the design of the buildings and structures of the TDF plant. In general, the design requirements comply with all appropriate Federal Regulations, and industry codes and standards. State and local government regulations, codes ard standards must be added to these criteria after a site is selected.

The criteria specified herein are based largely on criteria established for the breeder Large Developmental Plant study. It is implicitly assumed that most of the structural design criteria applicable to breeder and light water reactor plants are also applicable to fusion plants.

\section{Codes, Standards, and Regulations}

Unless specifically stated otherwise, the design of all buildings and structures is tentatively based on applicable portions of the following codes, specifications, industry standards, regulations, and other reference documents. Where conflict occurs between criteria, the more restrictive will apply, Where no date is shown, the latest issue will apply:

Governing Codes, Specifications, and Induscry Standards

- International Conference of Building officials, "Uniform Building Code" (UBC).

- American Institute of Steel Construction (AISC). "Specification for the Design, Fabrication, and Erection of Structural Steel for Buildings," 8th Edition 1978.

- American Welding Society (AWS)

- "Structural Welding Code" - AWS D1.1

- "Reinforcing Steel Welding Code" - AWS D12.1 
American Concrete Institute (ACI)

- "Building Code Requirements for Reinforced Concrete" - ACI $318-77$ and Comentary

- "Code Requirements for Nuclear Safety Related Concrete Structures" - ACI 349 - 76

- "Building Code Requirements for Minimum Design Loads in Buildings and ther Structures" - Anerican National Standards Institute (ANSI) - ANSI A58.1

- American Society for Testing and Katerials (ASTM). Applicable Standards of ASTM specifications are referred to in Section A.7, Construction Materials.

United States Nuclear Regulatory Comission (USNRC) Regulations and Standard Review Plans

- Code of Federal Regulations (CFR), Title 10 - Atomic Energy, Part 50, "Licensing of Production and Utilization Facilities," (10 CFR 50), including applicable Appendices $A$ through $M$.

- Code of Federal Regulations (CFR), Title 10 - Atomic Energy, Part 100, "Reactor Site Criteria," (10 CFR 100), including Appendix A thereto: "Seismic and Geologic Criteria for Muclear Power Plants," adopted November 27, 1973.

- USNRC - Regulatory Guides as follows:

- 1.59 Design basis floods for nuclear plants

- 1.60 Design response spectra for seismic design of nuclear power plants

- 1.61 Damping values for seismic design of nuclear power plants

- 1.76 Design basis tornados for nuclear power plants

- 1.92 Combination of wodes and spatial components in seismic response analysis

- USNRC - Standard Review Plans

- 3.8.4 Other seismic Category I structures 


\section{Site Characteristics}

A hypothetical site for the IDF was selected for the purposes of this study. This hypothetical site is generally compatible with installation at an established government nuclear reservation, such as the Idaho National Engineering Laboratory (INEL). This hypothetical site is also compatible with a significant number of potential U,S, sites. General information about the site is given below:

Geology and Seismology

$\begin{array}{lc}\text { Maximum MIE* ground acceleration } & 0.25 \mathrm{~g} \\ \text { Maximum MPE+ ground acceleration } & 0.13 \mathrm{~g} \\ \text { Ground response spectra } & \text { Use Regulatory Guide } \\ & 1.60 \text { assumptions } \\ \text { UBC seismic } & \text { Zone 2 }\end{array}$

Foundation material

Net allowable bearing capacity

$\begin{array}{ll}\text { Static } & 500 \mathrm{kPa} \\ \text { Dynamic } & 700 \mathrm{kPa}\end{array}$
Damping Use Regulatory Guide 1.61 assumptions
"S" Wave velocity $1200 \mathrm{~m} / \mathrm{s}$
Depth to bedrock At surface
Location of the nearest surface The site is located more capable of faulting than $8 \mathrm{~km}$ from a surface that is capable of faulting greater than $300 \mathrm{~m}$ in length.

Snow and ice load

$1 \mathrm{kPa}$

*MIE - Maximum intensity earthquake

+WPE - Most probable ear thquake 
Wind load and height for safety-related structures

Velocity

At a height above ground

Tornado loading

Region

Characteristics:

Maximum wind speed

Rotational speed

Maximum translational speed

Minimum translational speed

Radius of maximum rotational speed

Pressure drop

Rate of pressure drop
$145 \mathrm{~km} / \mathrm{h}$

$9 \mathrm{~m}$

Use Regulatory Guide

1.76, Region III, Design

Basis Tornado

Tornado missile characteristics

Missile

A. Wood plank

B. $152 \mathrm{~mm}$ pipe

(6-in. schedule 40)

C. 25 anm steel rod

D. Utility pole

E. 305 min pipe

(12 in. schedule 40)

F. Automobile
$386 \mathrm{~km} / \mathrm{h}$

$306 \mathrm{~km} / \mathrm{h}$

$80 \mathrm{~km} / \mathrm{h}$

$8 \mathrm{~km} / \mathrm{h}$

$46 \pi$

$10 \mathrm{kPa}$

4.1 $\mathrm{kPa}$ per second

Vertical velocities of $70 \%$ of the postulated horizontal velocities are acceptable on an interim basis, except for the small missiles, or missile 
$C$ in Spectrum 1, used to test barrier openings, which should be assumed at the same speed in all directions.

The impact velocities of the tornado-generated missiles are selected for tornado intensity Region III, consistent with the design basis tornado criteria. Tornado intensity regions are defined in Regulatory Guide 1.76.

\section{Seismic Design Classification of Structures}

The plant structures, systems, and components are classified into three categories from the standpoint of their importance to safety.

Seismic Category 1 Structures. Seismic Category I structures, systems and components are those necessary to ensure the capability to prevent or mitigate the consequences of accidents which could result in potential offsite exposures comparable to the guideline exposures of DOE. These structures shall be designed to remain functional in the event of an MIE. Furthermore, stresses in Seismic Category I structures shall be well within the elastic limits under the effects of an MPE.

The following are Seismic Category I structures:

- Reactor building

- Hot cell, radwaste, and reactor auxiliary building

- Tritium, heat transport and HVAC building

- Power supply, cryogenics, and diesel generator building

- Control building

- Control turnel

Non-Seismic Category I Safety Related Structures, Non-Seismic Category I structures are those whose failure could affect the integrity of adjacent safety related systems, structures, and equipment. The vent stack is a Non-Seismic Category I safety related structure. 


\section{Non-Seismic Category I Non-Safety Related Structures. These are}

structures whose failure could not affect the integrity of safety related systers, structures, and equipment.

All plant structures not listed in the previous two categories are classed as Non-Seismic Category I Nun-Safety related structures. This includes but is not limited to the following:

- Administration building

- Plant services building

- Cooling tower

- Demineralized water storage tank

- Air compressor station

- Water creatment plant.

- Pump house

o Raw water storage tank

- Fire water storage tank

- Off-site raw water supply line

o off-site power supply

- Guard house

\section{Plant Internal Loads}

Dead Loads. The dead loads include the weight of all permanent structural elements and the weight of all permanently attached equipment, piping, etc.

Live loads. The live loads include floor area loads (occupancy and laydown) and loads from movable equipment or structures.

Design Basis Accident Internal Pressure Load. The reactor building design basis accident internal pressure load is approximately $120 \mathrm{kPa}$. The positive accident pressure is caused by a cryogen release and helium pressurization accident. 
Accident Thermal Loads, Accident temperatures are unspecified at this time.

Loads Not Included. For simplicity, the following loads have not been included in the preconceptual structural design criteria:

- Missiles (other than tornado)

- Normal and accident pipe loads

- Dynamic earth pressures

- Compartment pressurization

\section{Design Bases}

The following sections establish factors of safety, codes, and ioading combinations to be used for all structures:

Factors of Safety. A minimum factor of safety shall be provided for all structures as shown below.

$$
\text { Minimum Factors of Safety }
$$

\section{Loading Conditions overturning sliding Flotation}
a) MPE
1.5
1.5
b) Wind
1.5
1.5
c) MIE
1.1
1.1
d) Tornado
1.1
1.1
e! Probable Maximum
Flood
f) UBC Earthquake
1.5
1.5

Loading combinations (a), (c), and (d) do not apply to Non-Category I Non-Safety related structures. Load combination (a) does not apply to Non-Category I safety related structures.

Seismic Category I Structures. Seismic Category I concrete structures are designed in accurdance with ACI-349 supplemented by ACI 318. Seismic 
Category I steel structures will be designed in accordance with the AISC Code. The applicable loading combinations will be as specified in the SRC Standard Review Plan 3.8.4.

Non-Seismic Category I Safety Related Structures. Non-Seismic Category I Safety Related reinforced concrete atructures are designed in accordance with ACI-318 for concrete structures. These structures will be designed in accordance with the loading combinations in Chapter 9 of ACI-318.

Non-Seismic Category I Safety Related steel structures are designed in accordance with the AISC code. Hind and seismic loadings are in accordance with ANSI A-58.1 and the UBC, reapective'

In addition to the above loading combinations, Non-Seismic Category I Safety Related structures are checked and strengthened as required to assure that they do not impose loads on a Category I structure or system during the design basis tornado or MIE event. For concrete structures under these conditions, the load factor for all loads shall be 1.0 The allowable stresses for st.eel structures shall be increased by 60 percent and the plastic section modulus of steel shapes shail be used. Only the main structural nembers are considered for these load combinations. These structures are allowed to be damaged during these events; for example, the struccures can be permanently deformed as a result of these extreme loadings.

\section{Non-Seismic Category I Non-Safety Related Structures. Non-Seismic} Category I Non-Safety Related Structures will be designed in accordance with ACI-318 for concrete structures. Steel structures shall be designed in accordance with the ASIC code. Wind and seismic loadings shall be in accordance with ANSI $A-58.1$ and the UBC, respectively.

\section{Construction Materials}

The principal construction materials for Seismic Category $I$ and Non-Seismic Category I scructures are concrete, reinforcing steel, structural steel, masonry, and metal decking and ire noted below: 
- Concrete design compressive strengths are:
Item
$\underline{f^{\prime}}$
All plant structures
$27 \mathrm{MPa}$
Lean concrete backfill and
electrical duct encasement
$17 \mathrm{MPa}$

Note: Compressive strength ( $\left.f c^{\prime}\right)$ refers to compressive strength at 28 days if only cement is used and to compressive strength at 90 days when pozzclan replaces part of the cement.

- Reinforcing steel shall be deformed billet steel, conforming to ASTM Designation $A-615$ grade 60

- Welded steel wire fabric shall conform to ASTM A-185 (plain wire) or $A-497$ (deformed wire)

- All structural steel shall be ASTM A-36

- Fasteners shall conform to ASTM A-307. High-strength bolts shall conform to AS DM $A-325$ or $A-490$

o Anchor bolts shall conform to ASTM A-307, A-36 or A-449

- Unless otherwise required by special conditions such as the control room penetration areas, metal decking shall be used for forming concrete slabs

\section{STRUCTURAL DESIGN DESCR IPTION}

A preconcepiual structural design is presented here on the most important TDF buildings and structures. A very limited structural analysis is performed in a few key areas of the TDF structures. This analysis is performed in accordance with the structural criteria discussed above. Possible alternate designs for some key areas and recomended future studies are also discussed.

\section{Reactor Building Complex}

This complex consists of the reactor building (including heat exchanger and radwaste areas' hot cell building and tritium building. These buildings have been combined into one large complex sharing a common 
basemat. For the most part, these bu: idings are massive reinforced concrete structures which use structural steel members only to support concrete weight during forming and thereby eliminate expensive and time consuming shoring and form removal operations. The most significant exceptions to this are the toofs of the reactor and hot cell buildings which use steel trusses to carry both dead weight and seismic loads. Concrete roof and floor slabs are designed to act as diaphragms to transfer lateral loads to the concrete walls which are designed as shear resisting elements. The foundation mat is designed as a slab on an elastic foundation. The thickness of walls and slabs surrounding radioactive areas is generally governed by shielding requirements.

The most significant structural feature of the reactor building complex are the $2 \mathrm{~m}$ thick walls, floors, and roofs required for shielding in the reactor building and hot cell. This, combined with the large distances over which these structural elements must span, constitute a very significant cost factor. The large thickness required for shielding increases structual mass which results in high gravity and seismic loads.

Two areas of high sensitivity to these loads are the roofs of the reactor building and hot cell which have large clear spans. The design selected is a deep steel truss system with rolled beams acting as purlins to support a steel deck. This design is selected because of its relative ease of construction: First, the trusses are placed on the walls and then the secondary framing and steel decking is erected on the trusses. Next, the reinforced concrete roof slab is placed.

The steel truss concept is selected over the following two alternate methods:

- Barrel Vault (Arch shaped roof) - Since the large concrete thickness is required for shielding, not strength, its thickness must be held constant and so the usual economy of a barrel vault cannot be utilized. Also, due to curvature of the vault, more concrete is required, compared to the flat roof system. Moreover, the barrel vault requires a steel truss for form support. 
- Post-tensioned T-beans with a reinforced concrete slab placed on top. The main disadvantage of this concept is the large crane capacify and time required to lift the heavy T-beams into position. This lifting problem is most critical on the high reactor building as opposed to the hot cell roof. Even with this disadvantage, the post-tensioned T-beam concept is the more attractive of the two alternate concepts considered due to its low fabrication cost. A future cost comparison study ( $\mathrm{T}$-bean versus steel truss) is recormended.

Another area of high sensitivity to the high building weight caused by the large shielding thickness is the limited span that can be tolerated by the basemat due to the soil pressure. This requires that the basemat be stiffened by walls (and the first floor, where possible) to keep basemat thickness and reinforcement at reasonable levels. Future studies should investigate the tradeoff between incorporating such walls into the building layout vs. eliminating some of them and providing more basemat thickness and reinforcement.

Another area of high sensitivity to the required shielding thickness is the induced seismic load on the walls of the reactor building, particularly the east wall. Most of these heavy walls span large distances without stiffening from adjacent floors or walls. This configuration appears feasible, but the reinforcement levels required for seismic will be very high in the east wall. Future studies should consider alternative designs that stiffen this wall with pilasters.

\section{Tritium, Heat Transport, and HVAC Building Complex}

The tritium, heat transport, and HVAC building does not have the high shielding requirements required by the reactor and hot cell buildings. However, since this building forms one corner of the reactor building complex, its structure is heavier than what would be required if it were allowed to stand alone. It is recommended, therefore, that future studies investigate the feasibility of extending the length of the hot cell to equal the length of the reactor building. This would allow the expensive, long, clear, east-west span of the hot cell building toof to 
be reduced. The tritium heat transport and HVAC building could then be a separate structure or placed over the extended hot cell building adjacent to the reactor.

Another recomendation for future study would be to lower the extended hot cell building such that the hot cell basemat is at the same elevation as the reactor building basemat. This would put the entire basemat at one elevation and place the floor of the local control and viewing corridor approximately at grade.

Power Supply, Cryogenics, and Diesel Generator Building (Power Supply Complex)

This is a Category I structure that is a completely separate structure from tine reactor building complex. The power supply complex has no radiation shielding requirements, and tornado shielding will require much thinner walls than the adjacent reactor building complex ( 2 m walls). If the two structures were joined into one large structure, the power supply complex would have required significant strengthening to take the large soil pressure reaction that would be induced in the power supply complex basemat. As a separate building it can be an economical light steel structure with relatively thin reinforced concrete floors and walls and $a$ reduced basemat thickness. The piping and electrical connections between the two complexes, however, must be able to withstand relative seismic and differential settlement displacements.

\section{Reactor Support}

The reactor has three support regions:

- North end cell support

- Anchor cells and center cell support

- South end cell support 
The north and south end cell supports are attached directly to the operating floor (El, $100 \mathrm{~m}$ ) of the reactor building which has been reinforced with walls directly below the supports. Horizontal loads are taken by the operating floor acting as a diaphragm. The center cell support is attached directly to the basemat as shown.

For the purposes of this study, it has been assumed that the south end cell provides north-south, east-west, and vertical restraint. The north end cell support provides only east-west and vertical restraint and the center cell support provides only vertical restraint. This arrangewent allows machíne thermal movement.

The center cell support is the most critical from a structural viewpoint, since it is required to be small in plan to permit maintenance of the neutral beam injectors and yet it must be 13 meters high. This design concept relies on the structural strength of the reactor so that the center cell and anchor cells transmit their east-west seismic loads to the north and south end cells. Note that since the south end cell support is assumed fixed, the center and anchor cells must also transmit the north-south seismic load of the north end cell to the south end cell support. It is not known at this time if this is feasible. If the center cell support also requires east-west restraint, then the single cantilevered column support will most likely not be acceptable since it probably lacks the necessary horizontal stiffness compared to the stiffness of the center cell and anchor cell structures. In this case, future studies should investigate the following two alternate concepts:

- A concrete column with a horizontal reinforced concrete, east-west, strut to the west wall at the 100 meter elevation and an optional similar strut in the north-south direction to the floor at elevation $100 \mathrm{~m}$. This will horizontally stiffen the center anchor support significantly.

- The same scructural configuration described above except that the column and $s$ trut $(s)$ are each made of four wide-flange steel members laced together to form box sections. 
Appendix B

IDE PLOT PLAN AND PLANT ARRANGEMENT DRAH INGS

The drawings for the plant arrangement are as follows:

Drawing No.

SK-C-1000

SK-P-1001

SK-P-1002

$\mathrm{SK}-\mathrm{P}-1003$

$\mathrm{SK}-\mathrm{P}-1004$

SK-P-1011

SK-P-1012

SK-P-1013

SK-P-1014
Title

Plot Plan

General Arrangement Reactor and Support Buildings

Plan Below El. $130.0 \mathrm{~m}$

Plan Below El. $113.0 \mathrm{~m}$

Plan Below E1. $106.0 \mathrm{~m}$

Plan Below El. $98.0 \mathrm{~m}$

Section A-A

Section B-B

Section C-C

Section D-D 


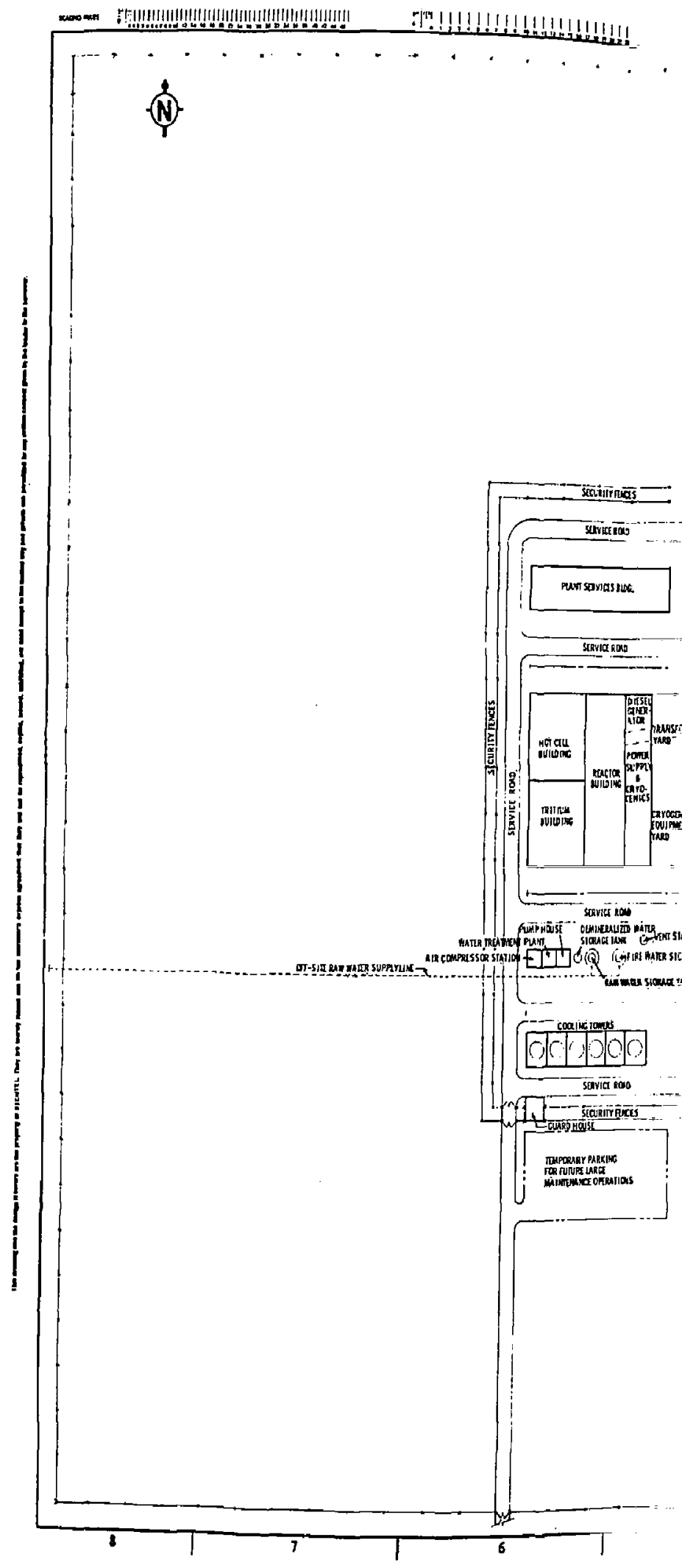




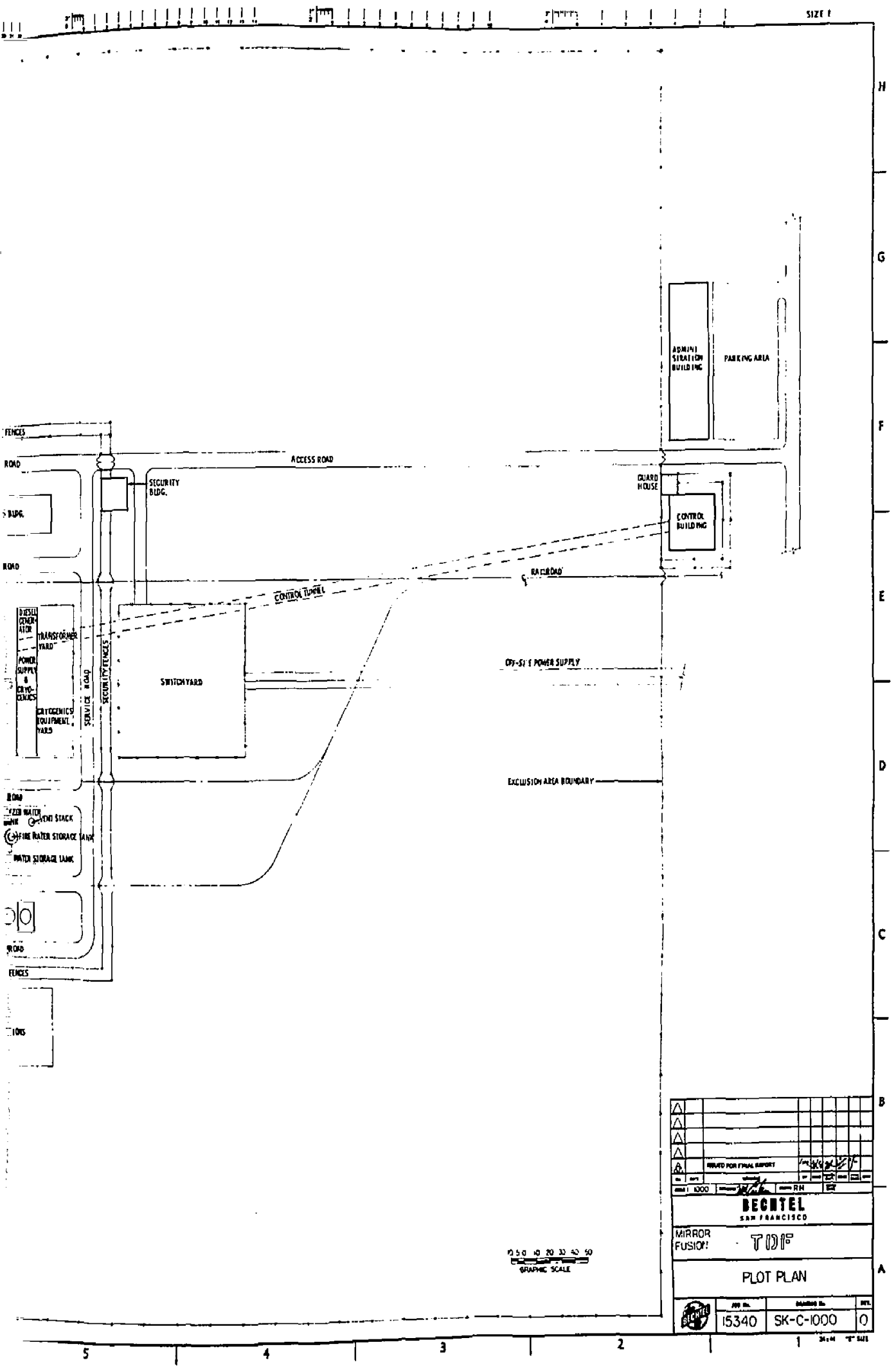




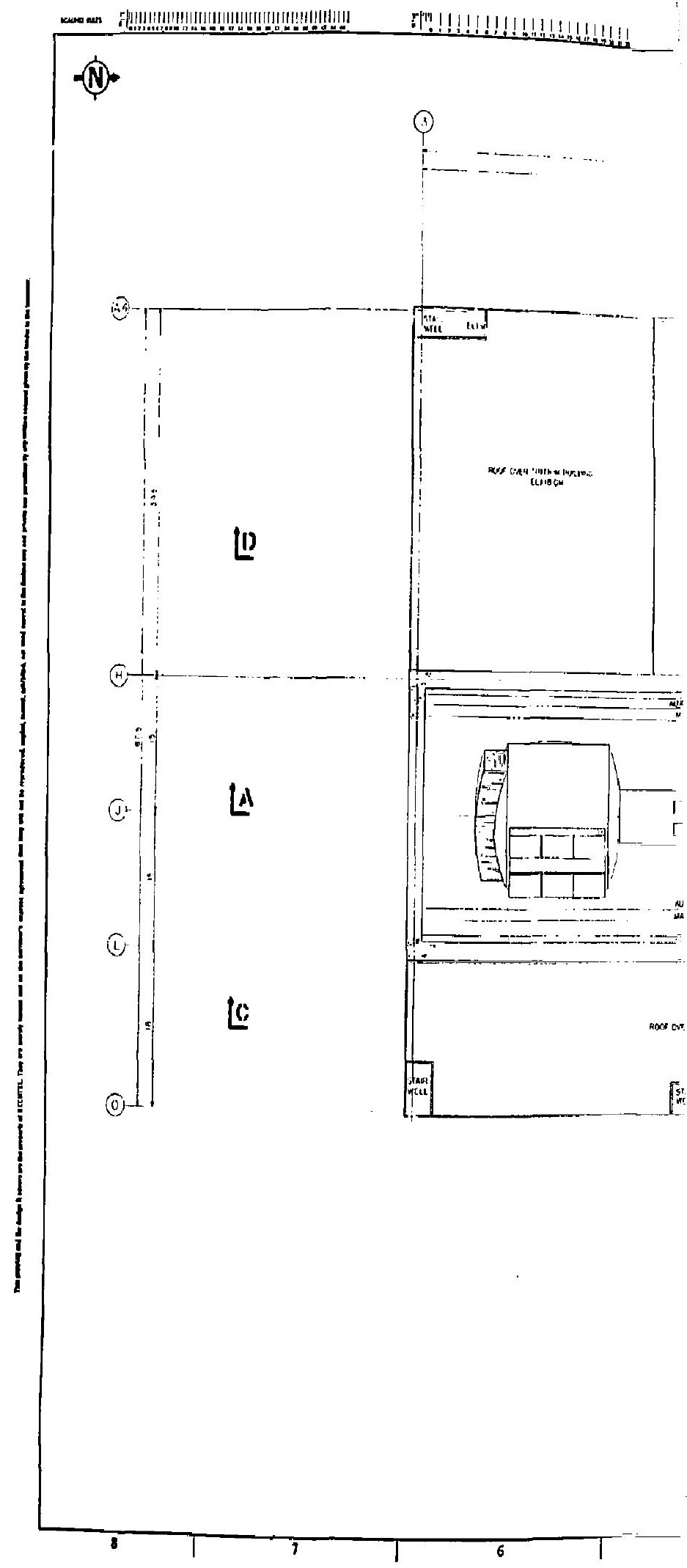




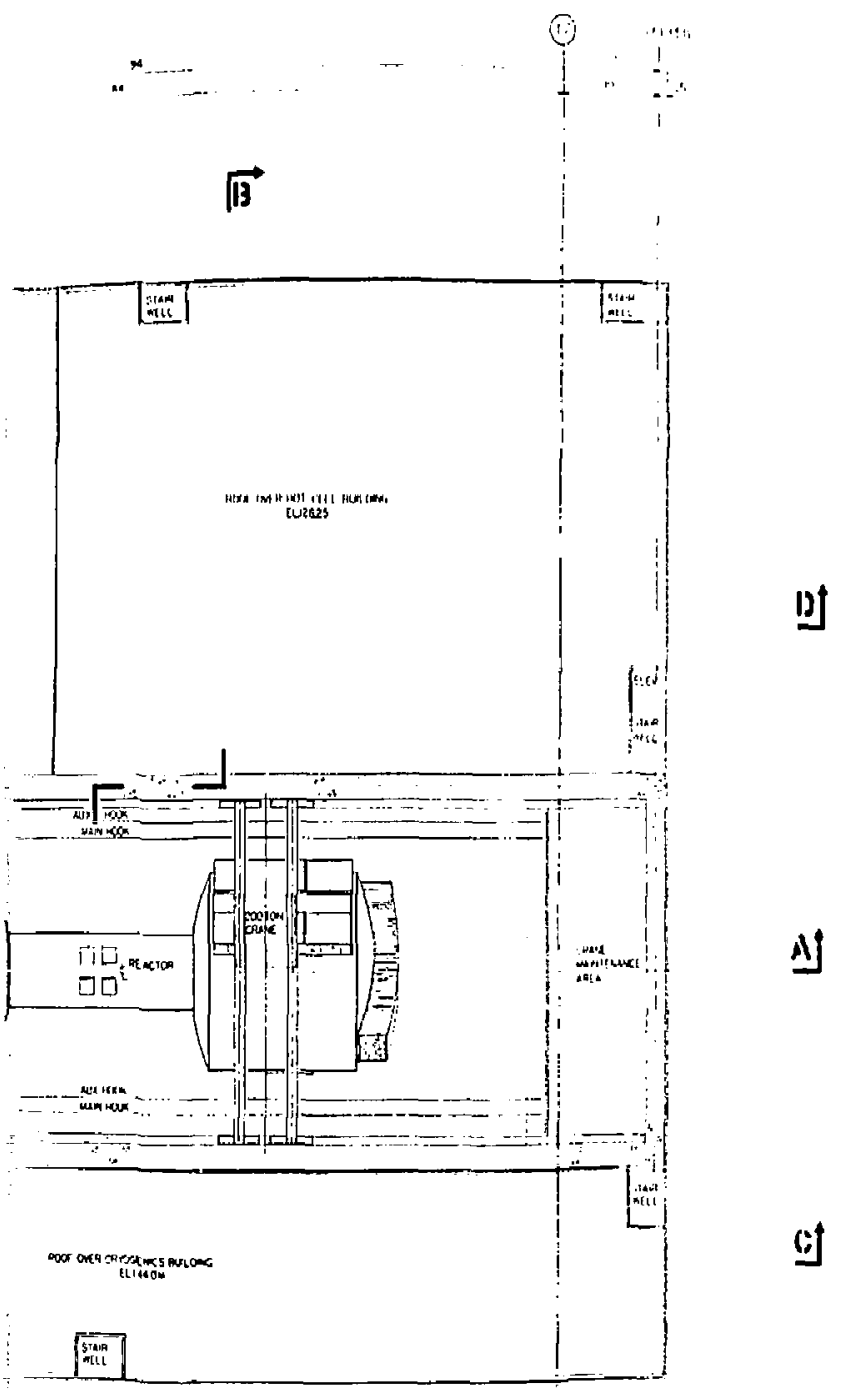

$\stackrel{\text { 自 }}{ }$

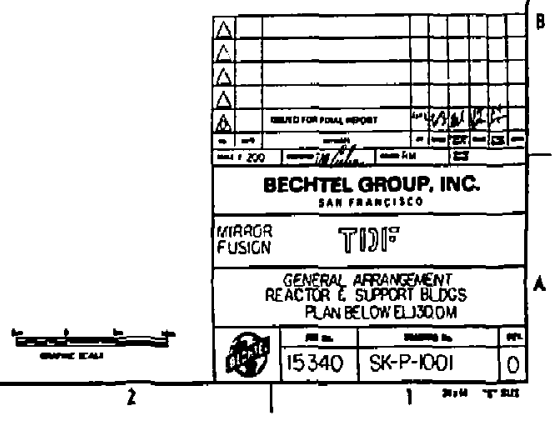


- (i.

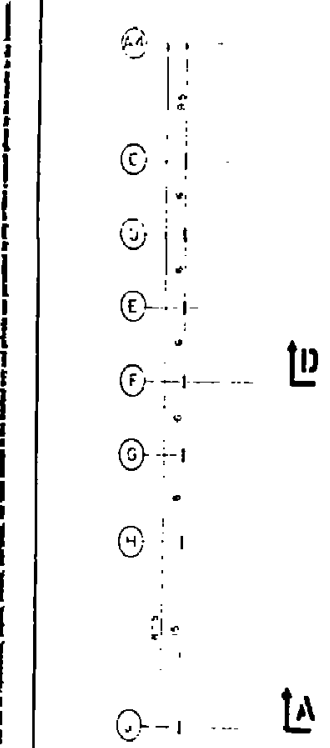

(3) (4) i5) (5) 77 (5)

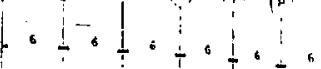

4<smiles>CC(C)(C)C</smiles>
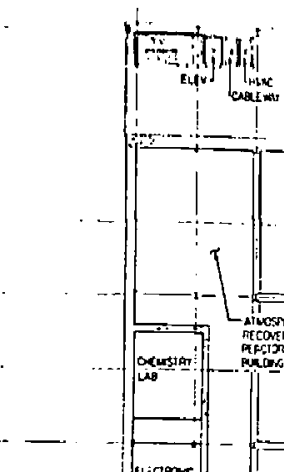


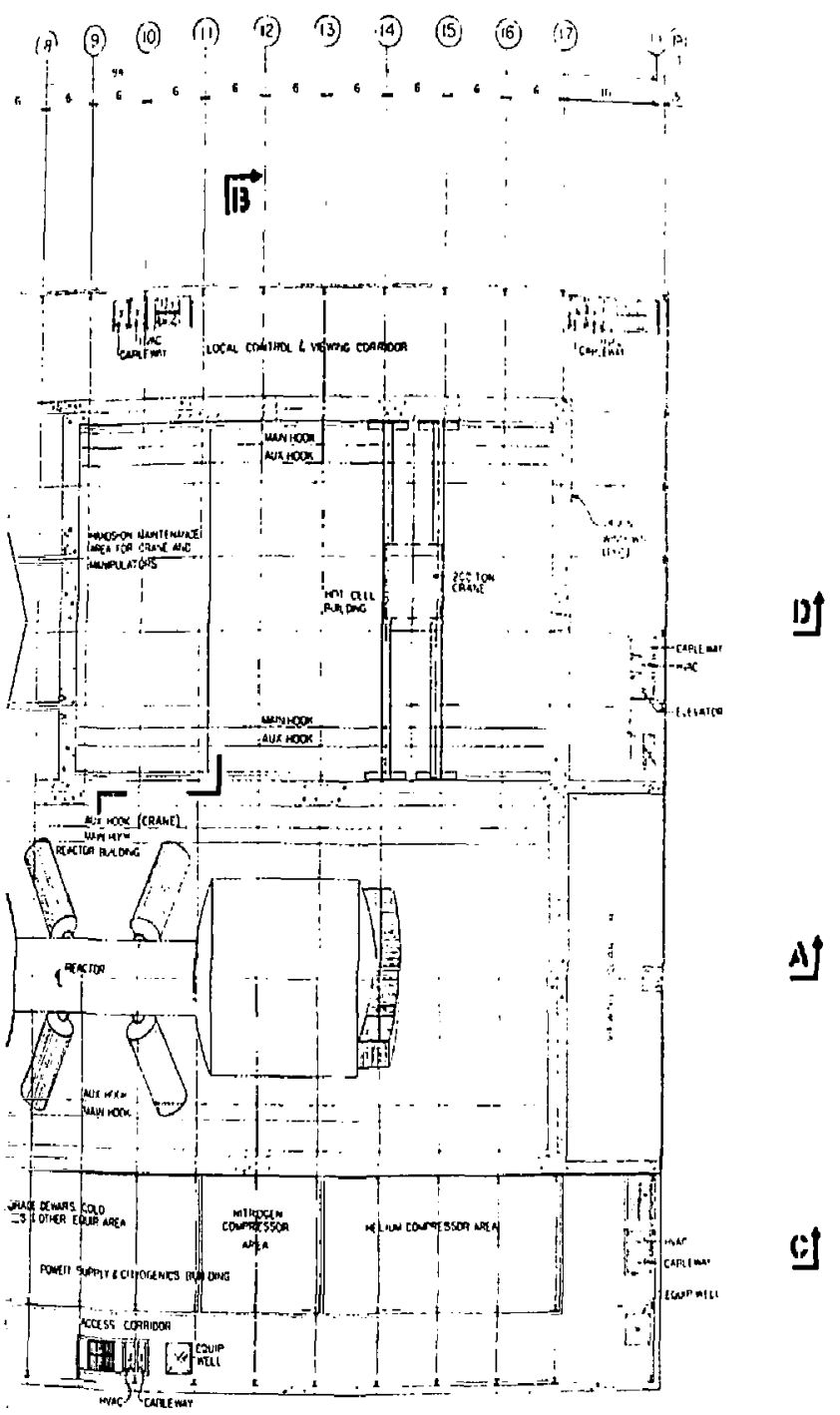

If

$\Delta$

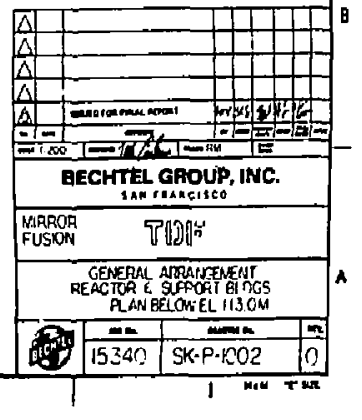




\section{(N)}

(3) (4) 5) i) iो ,

$\therefore 5-5-5-5$.

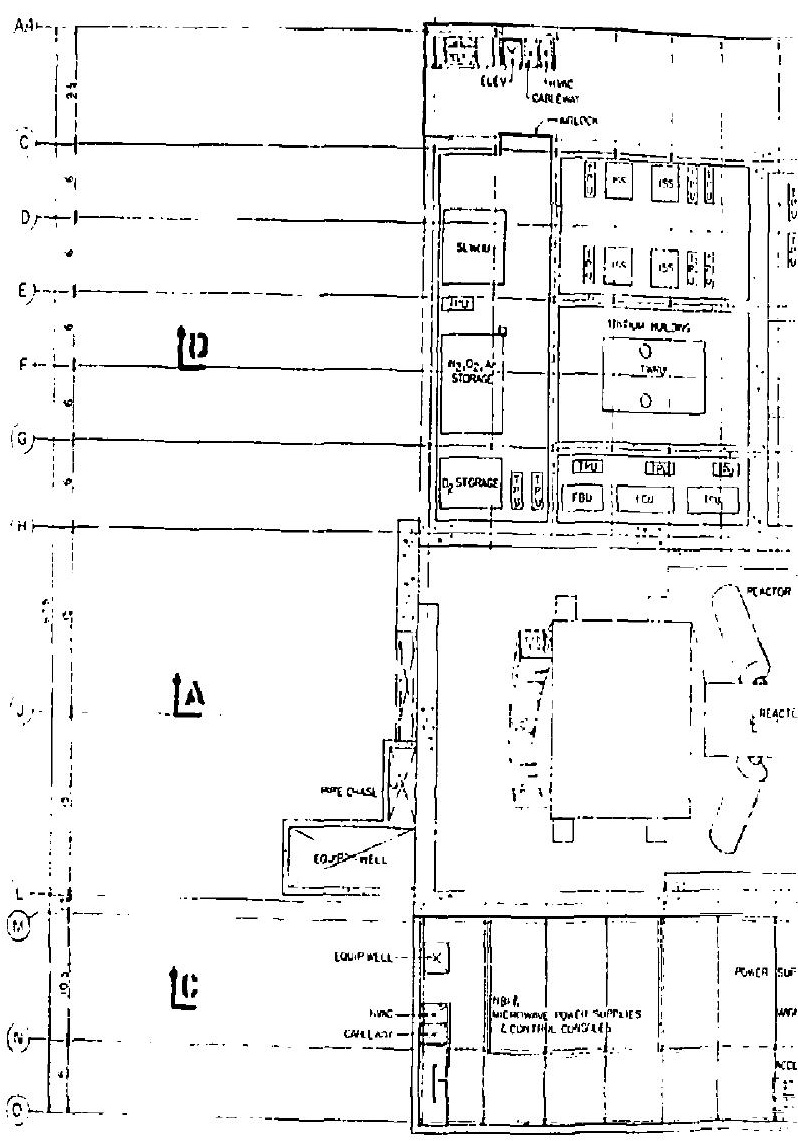


.

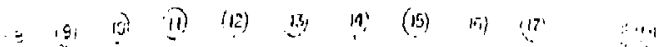

$\therefore+6-6-6-6-6-6$

$\sqrt{13}$

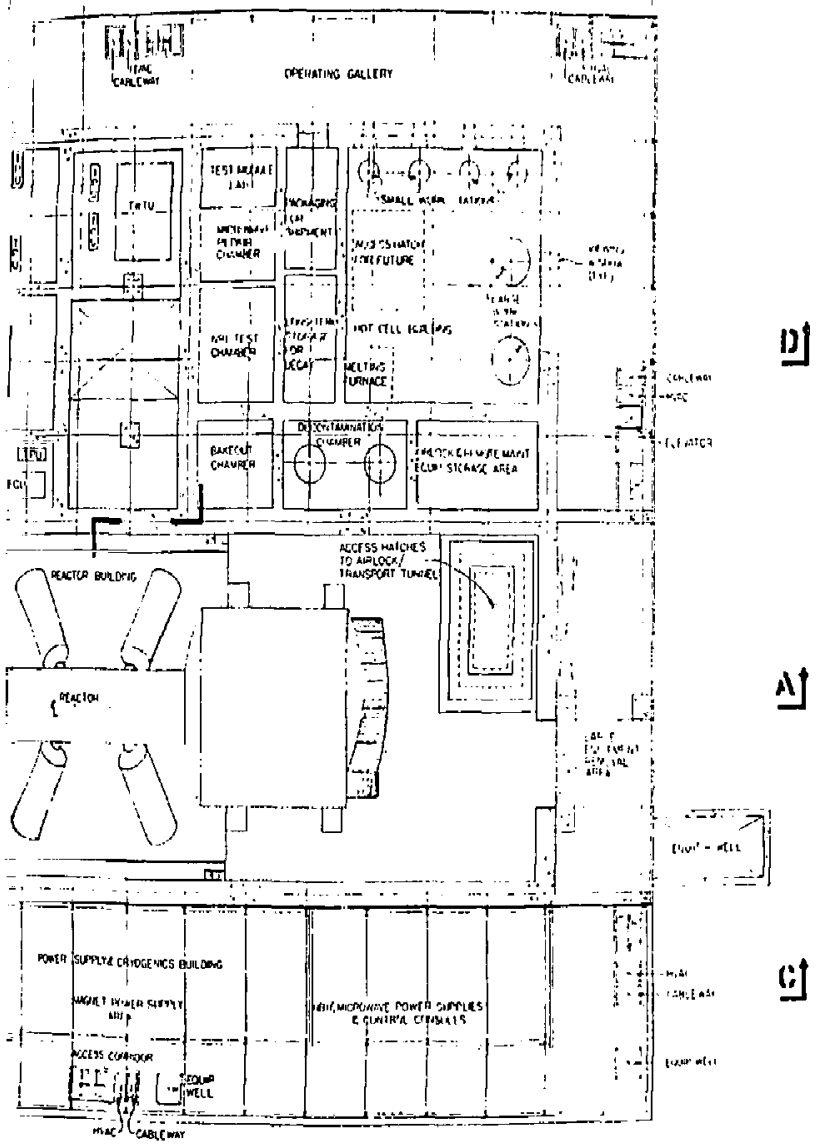

1]

L

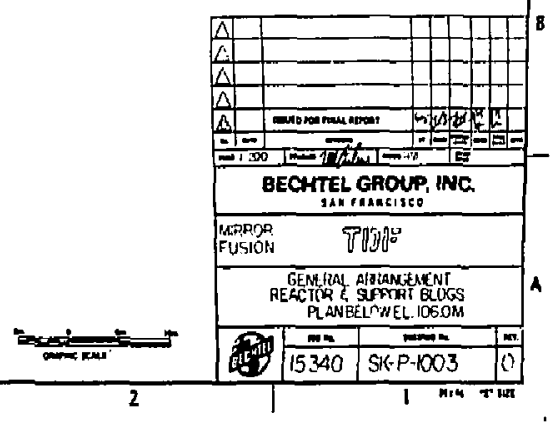


(N).
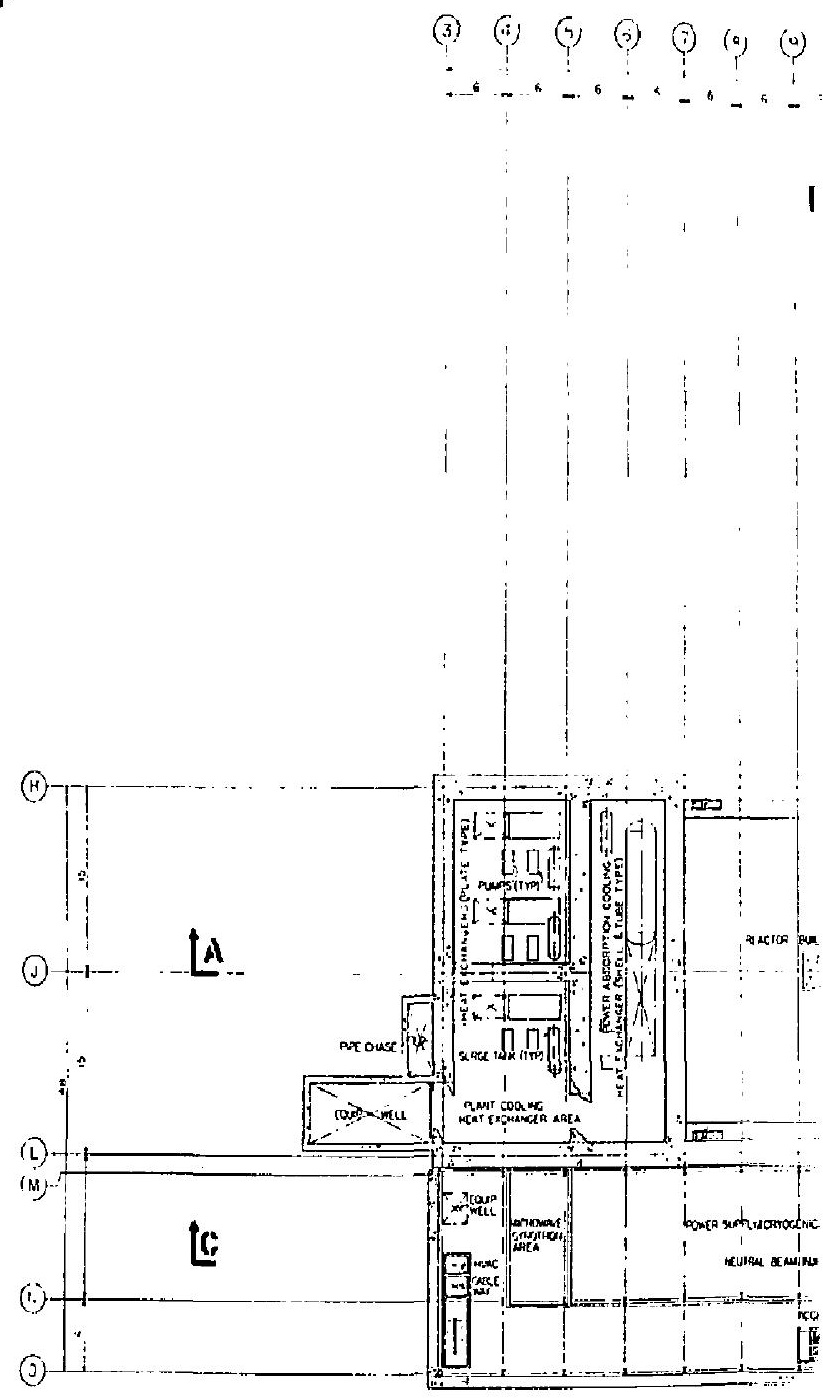


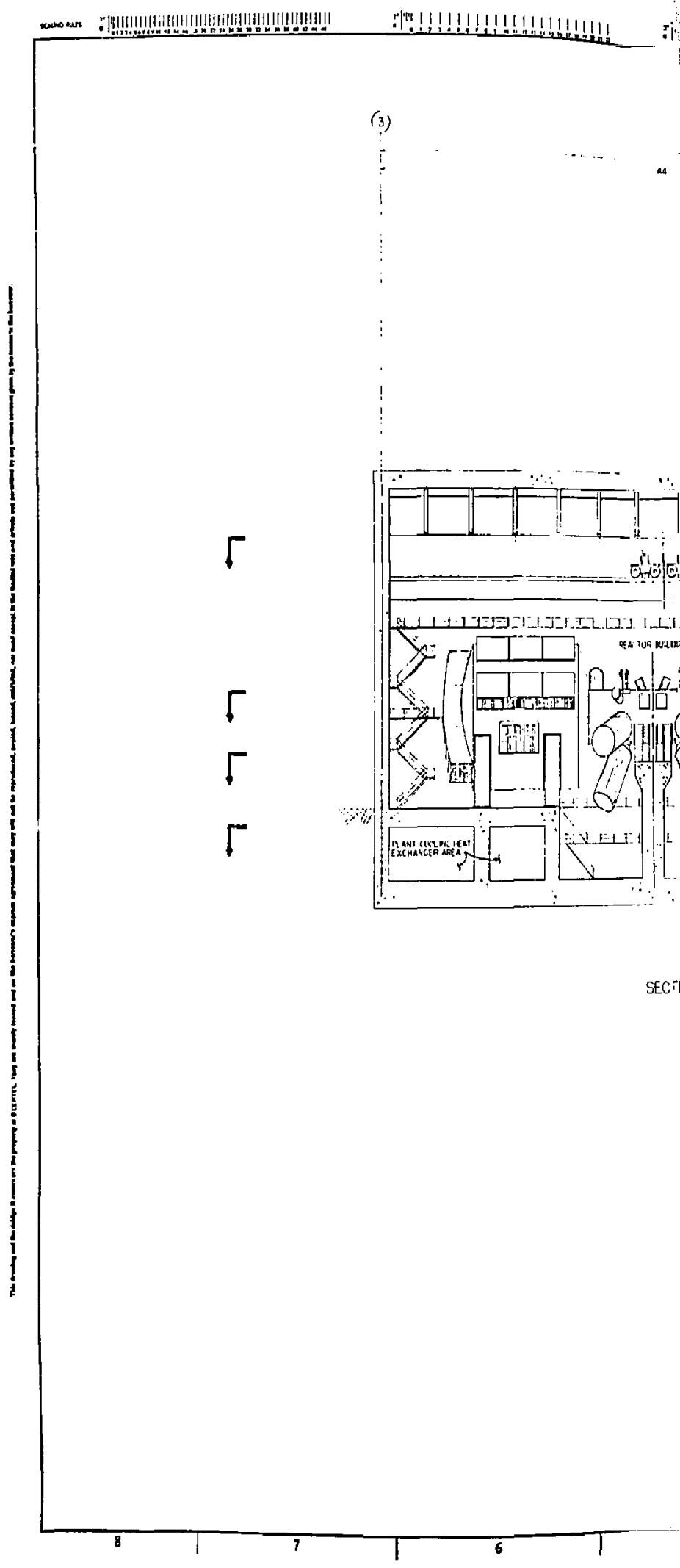




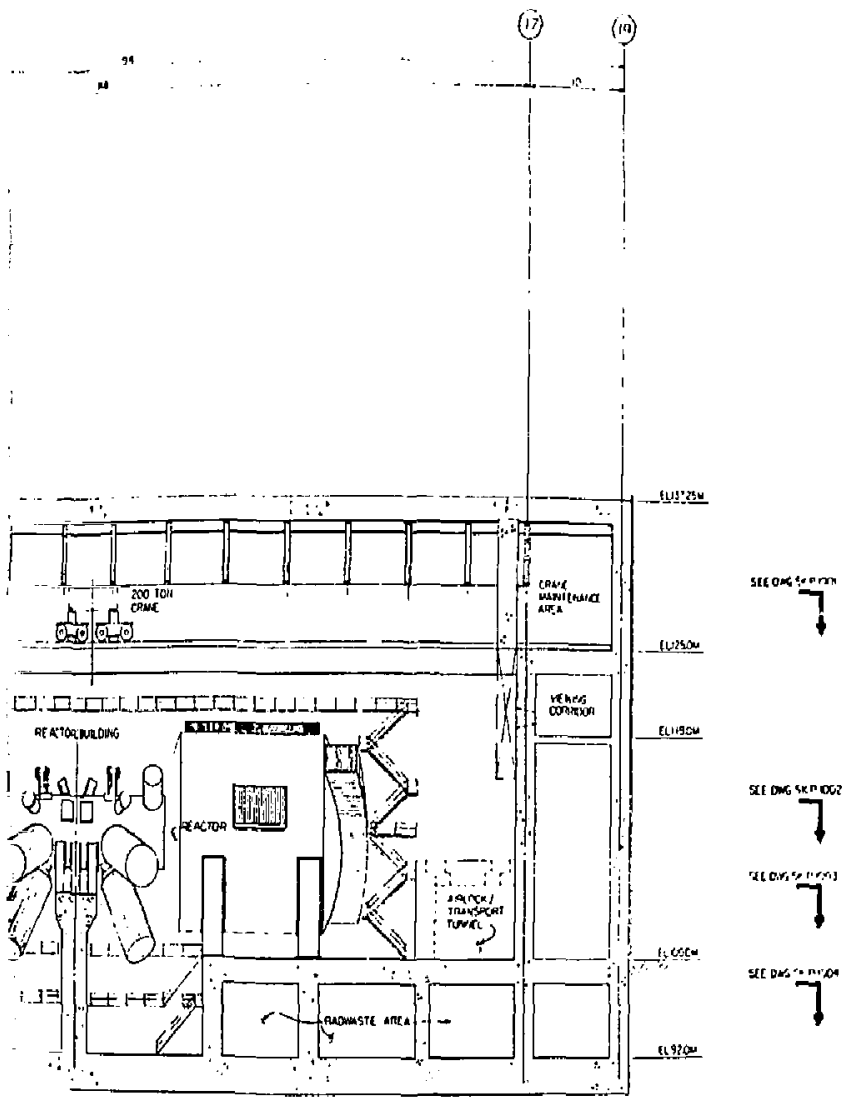

SECTION $\boldsymbol{A}-\boldsymbol{A}$

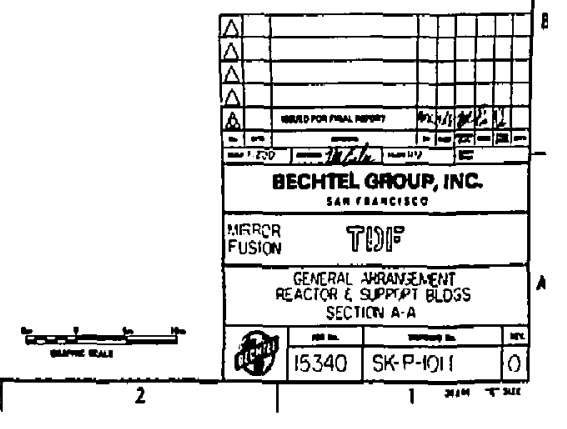




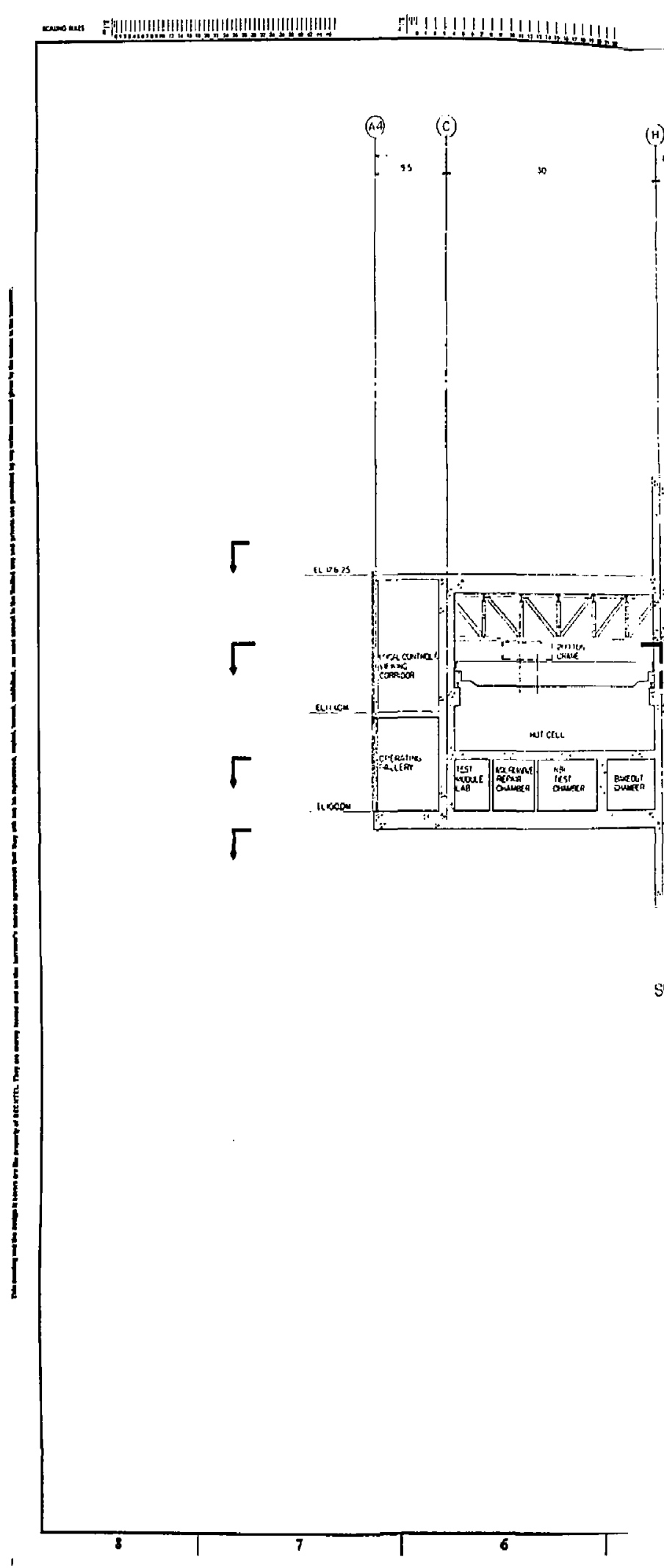




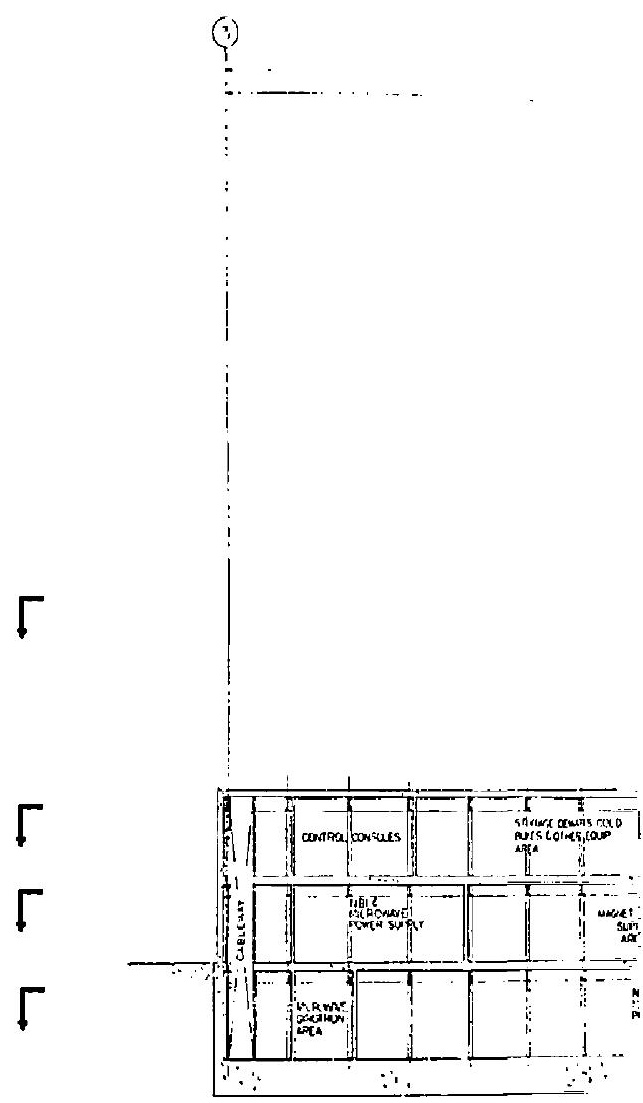





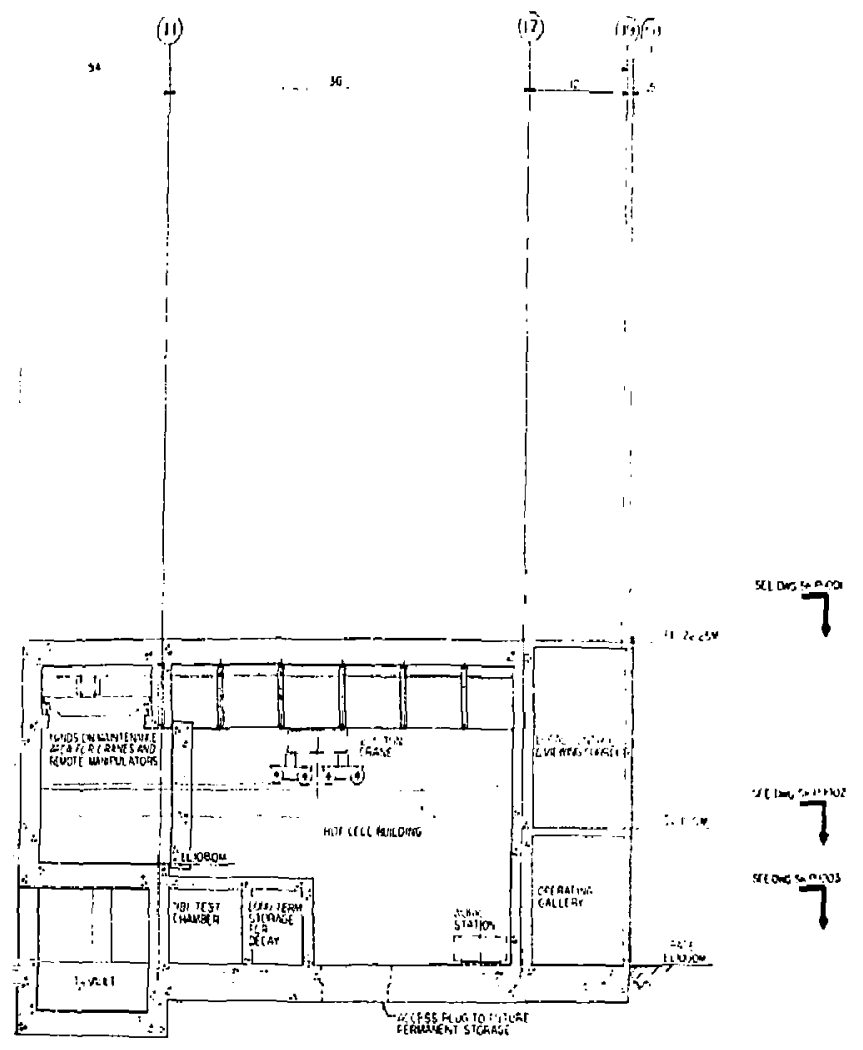

SECTION D-D

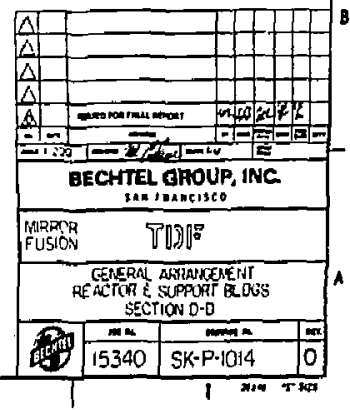

